\title{
Efficient Clean-up of Oil Spilled Shorelines Using the Compressed Air Jet System and Concomitant Microbial Community Analysis
}

\author{
Jae-Soo Chang ${ }^{1}$, Kyung Hee Kim ${ }^{2}$, Jae Shik Lee ${ }^{2}$, Kalu I. Ekpeghere ${ }^{1}$, and Sung-Cheol Koh ${ }^{1 *}$ \\ ${ }^{1}$ Department of Environmental Engineering, Korea Maritime University, Busan 606-791, Republic of Korea \\ ${ }^{2}$ JH Green, Inc., Goyang 410-350, Republic of Korea
}

\section{압축공기 분사시스템을 이용한 유류오염 해안의 효율적 정화 및 이에 따른 미생물군집분석}

\author{
장재수 $^{1} \cdot$ 김경희 $^{2} \cdot$ 이재식 ${ }^{2} \cdot$ Kalu I. Ekpeghere ${ }^{1} \cdot$ 고성철 $^{1 *}$ \\ ${ }^{1}$ 한국해양대학교 환경공학과, ${ }^{2} \mathrm{JH}$ 그린 주식회사
}

(Received December 4, 2013 / Accepted December 18, 2013)

\begin{abstract}
The objectives of this study were to investigate effectiveness of the Compressed Air Jet (CAJ) System for cleaning up shorelines contaminated with crude oils and to examine effects of the system on total petroleum hydrocarbon (TPH) removal and microbial community changes before and after remediation of the oil-contaminated shorelines. These data will lead to better understanding of optimized remediation process. About $66 \%$ of TPH reduction was observed when the contaminated site was treated with the CAJ System 2, 3, 4, and 5 times. This treatment system was more efficient than the seawater pumping system under similar treatment conditions (by $40 \%$ ). By the way, little oil degrader communities were observed despite a potential function of the air jet system to stimulate aerobic oil degraders. The apparent low population density of the oil degraders might be as a result of low concentration of TPH as a carbon source and limiting nutrients such as nitrogen and phosphorus. It was proposed that the CAJ System would contribute significantly to removal of residual oils on the shorelines in combination with addition of these limiting nutrients.
\end{abstract}

Keywords: compressed air jet, oil spill, sediment remediation, shoreline, total petroleum hydrocarbon (TPH)

The industrial development accompanied by population increase caused rapid consumption of oils. As a result, history observed many oil spill accidents at various levels. In 2007 one of the worst oil spill accidents in Korea happened due to a broken oil tanker, Hebey Spirit, off Taeahn coast, being recorded as one of the biggest international oil spill accidents. Oil spilled in the marine environment typically causes both immediate and long-term environmental damage (Bejarano and Michel, 2010). Once oil is spilled by broken tankers, pipelines or offshore oil rigs, it usually drifts into the shorelines and massively contaminates them and then goes through physicochemical and biological dispersion or degradation (Seo and Song, 1994; Koh et al., 1998). While low molecular weight and volatile compounds are dissipated, the residual oil (usually Bunker $\mathrm{C}$ oil and

*For correspondence. E-mail: skoh@kmou.ac.kr; Tel.: +82-51-4104418; Fax: +82-51-410-4415 asphaltenes, etc.) then can sorb to mudflat, sand, gravel or rock, where they become more difficult to be removed. The oil sorbents and chemical surfactants for oil washing and dispersion have been used to clean up oil spills on the shorelines but they are costly and causing toxicities in the ecosystem (Seo and Song, 1994). Various bioremediation technologies have been effectively used to circumvent these problems (Altas, 1981; Altas and Bartha, 1992; Zhang and Miller, 1994; De Acevedo and McInnerney, 1996; Choi et al., 1997; Roenberg and Ron, 1997; Sprocati et al., 2012) but these are rather time consuming and selective. Several factors which affect the rate at which indigenous or bioaugmented microbes function in affected sites have been discussed (Fernández-Luqueño et al., 2011). In this study an alternative clean up system has been developed to meet a rapid removal of high contaminated oil from various substrates such as sediments, gravels, and rocks as well as to provide air to the polluted environment. The Compressed Air-Jet (CAJ) System developed 
Table 1. Experimental conditions for a field demonstration of the remediation by the Compressed Air Jet (CAJ) System

\begin{tabular}{ll}
\hline Parameter & Experimental conditions \\
\hline Date & $8: 00$ am, Oct. 28,2010 \\
Temperature & Air $8{ }^{\circ} \mathrm{C}$; water $10^{\circ} \mathrm{C} ;$ soil $12^{\circ} \mathrm{C}$ \\
Test site: & Taeahn, Choongnam, Korea \\
Equipments tested and running conditions & High pressure water pump (flow rate: $\left.80 \mathrm{~m}^{3} / \mathrm{h}\right)($ as a control) \\
Test runs and time taken & Air jet system with compressor $\left(3-5 \mathrm{MPa} / \mathrm{kgf}^{2} / \mathrm{cm}^{2}\right)$ \\
& 5 runs; 30 min per each run \\
Test area & High pressure pump: $250 \mathrm{~m}^{2}(5 \mathrm{~m} \times 5 \mathrm{~m})$ \\
Soil sample collection & Air jet system: $300 \mathrm{~m}^{2}(5 \mathrm{~m} \times 6 \mathrm{~m})$ \\
\hline
\end{tabular}

by JH Green, Inc. (Korea) can easily reach, separate and remove spilled oils clinging to rock and grain of sand. The CAJ System generates high pressure bubbles and makes the air bubbles collide one another in aqueous environment to form micro air bubbles ultimately used to effectively separate contaminated materials from the sorbed phase. The micro air bubbles float the precipitated oils, and floated oils can be easily removed by absorbing cloths. The CAJ System is economical, eco-friendly remediation technology, and could be effective for the subsequent bioremediation compared to conventional methods. The objectives of this study were to investigate effectiveness of the CAJ System for cleaning up shorelines contaminated with crude oils and to examine effects of the system on total petroleum hydrocarbon (TPH) removal and microbial community patterns in oil-contaminated shorelines.

\section{Materials and Methods}

\section{On-site test of the CAJ System}

A field demonstration of the remediation was accomplished under the experimental conditions shown in Table 1. The remediation process using the CAJ System generally followed the procedure described below: geological analysis; determination of oil spill area; set-up of oil boom and fence; piling up of gravels and sands; treatment of contaminated soil and sediment using the CAJ System in the presence of flowing tide; removal of floated oils using sorbents; ground leveling. The CAJ System (Fig. 1) is used to generate air bubbles including micro air bubbles which can float spilled oil in the sediment or on the solid surface. Air bubbles could float precipitated oils along with water and sediments (soils). Some volatile gases and non-volatile compounds appeared to be separated and the floated oils were able to be easily removed by absorbing cloths. Air bubbles could float the precipitated oils along with water and sediments (soils) (Fig. 2A and 2B). The CAJ System would make the subsequent bioremediation more effective as long as limiting nutrients and other environmental conditions are met.

\section{Soil sampling}

Sediment soils for the total petroleum hydrocarbon (TPH) and microbial community analysis were taken following the protocol (ES 07130) from the Official Standard Methods for Contaminated Soils (Ministry of Environment, 2009).

\section{Analysis of TPH}

TPH analysis was performed based on the protocol (Item 18) from the Official Standard Methods for Contaminated Soils (Ministry of Environment, 2009). The instrument used was GC-FID: Model, QP-5000 (Shimadzu, Japan) with HP-5 capillary column $(50 \mathrm{~m} \times 0.2 \mathrm{~mm} \times 0.33 \mu \mathrm{m})$ and analytical conditions
(A)

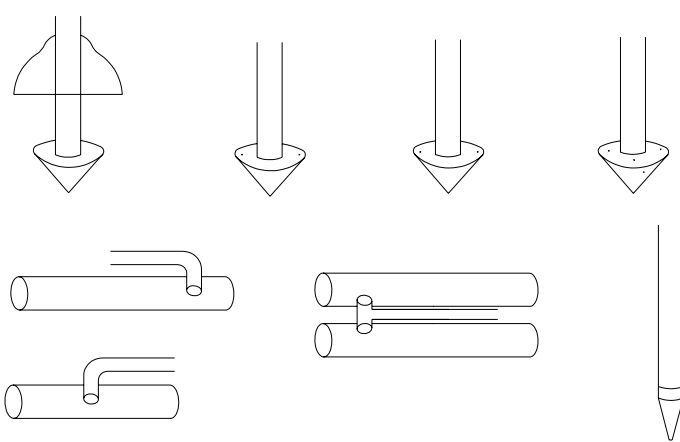

(B)

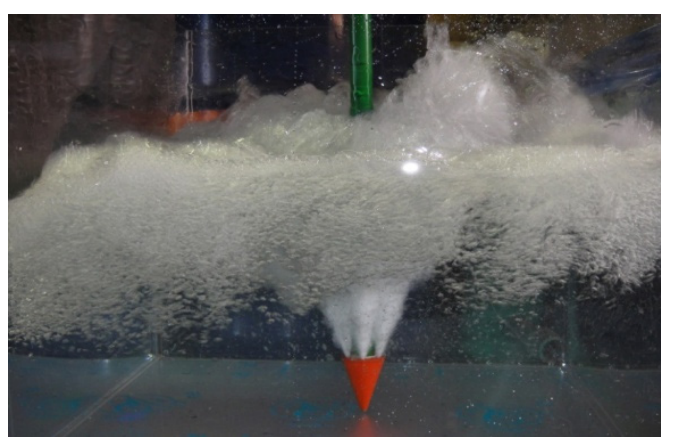

Fig. 1. Various types of compressed air-jet system (A) and operation of the bar type air jet system in water (B). 
(A)

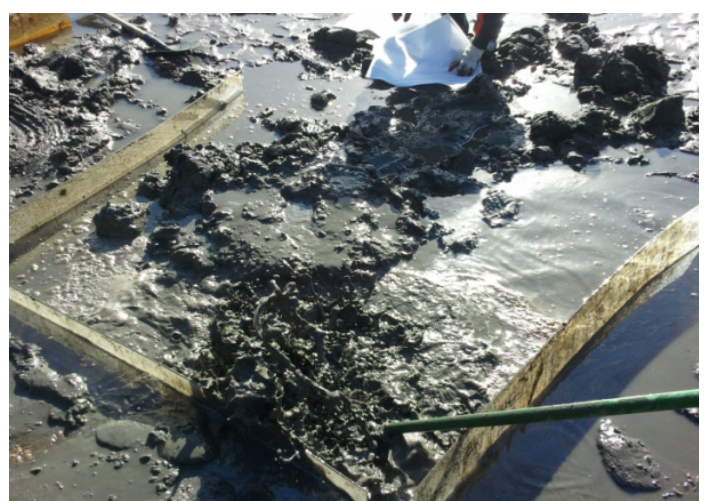

(B)

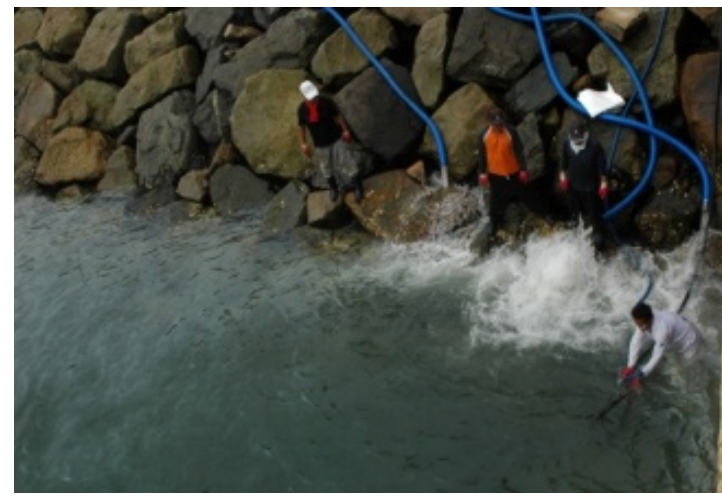

(C)

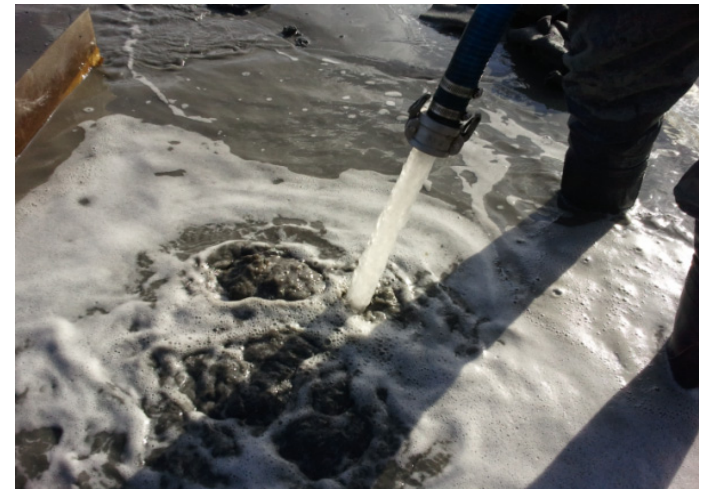

Fig. 2. Clean up of field precipitated oils in the sediments (A) and on the rock surfaces by the air jet system (B) and in the sediments by water pumping $(\mathrm{C})$.

were: temperature gradient $2 \mathrm{~min}$ at $80^{\circ} \mathrm{C}$, temperature increase $8^{\circ} \mathrm{C} / \mathrm{min}$, and $10 \mathrm{~min}$ at final temperature $\left(320^{\circ} \mathrm{C}\right)$; temperatures at inlet and detector were $300^{\circ} \mathrm{C}$ and $320^{\circ} \mathrm{C}$, respectively; nitrogen gas as a carrier gas; sample injection $1 \mu \mathrm{l}$.

\section{Microbial community analysis}

Total DNA extraction was made using Fast DNA extraction Kit (Bio101, USA) and PCR-DGGE was conducted for the microbial community analysis following the previous report (Ekpeghere et al., 2009).

\section{Results and Discussion}

\section{Clean-up of the contaminated shorelines using the CAJ System}

In the on-site demonstration test, after treating the site with the CAJ System once, TPH was reduced by $26 \%$ compared to that before the treatment (control: bt) (Fig. 3). About $66 \%$ of TPH reduction was observed when the contaminated site was treated with the CAJ System 2, 3, 4, and 5 times (a-2, a-3, a-4, and a-5). After treating the site with the CAJ System 2 times, no further decrease of TPH was observed, indicating the TPH removal from the site was quite effective. In case of seawater pumping, however, reduction of TPH was observed about $60 \%$ after treating the site once and twice, and the reduction of TPH was about $40 \%$ and $25 \%$ after treating the site 3 times and 4 times, respectively. This indicates that in the seawater pumping, removal of sorbed oil was not complete resulting in sorbed oil release at more than 2 times of seawater washing. Overall, the seawater pumping showed less oil removal efficiency compared to the CAJ System.

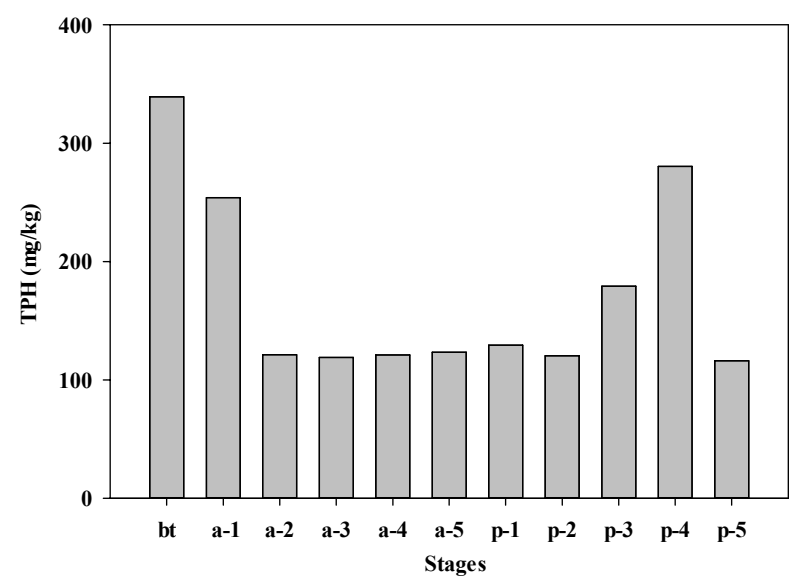

Fig. 3. Effects of the air jet and pumping treatments on TPH removal in a demonstrated site; bt, before treatment (control); a-1, 2, 3, 4 and 5 , air jet system treatment; p-1, 2, 3, 4 and 5, water pumping system; all data were the average value of duplicate samplings . 


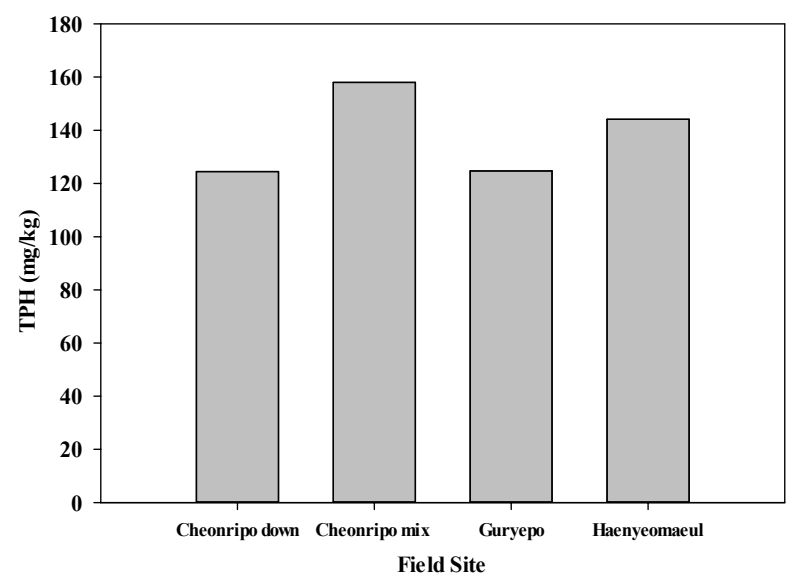

Fig. 4. Effects of the air jet treatment on TPH removal in the field sites (Haenyeomaeul: pumping as control); all data were the average value of triplicate samplings.

Treatments with the CAJ System were also examined in other contaminated field sites (Cheonripo down, Cheonripo mix, and Guryepo) with Haenyeomaeul as a control (Water pumping). After the treatment, the concentrations of TPH were about $14 \%$ lower in Cheonripo down and Guryepo than Haenyeomaeul (control) but the levels of TPH in Cheonripo-mix were about $7 \%$ higher that the control. This indicates TPH treatment effects might be variable depending on the treated sites (Fig. 4).

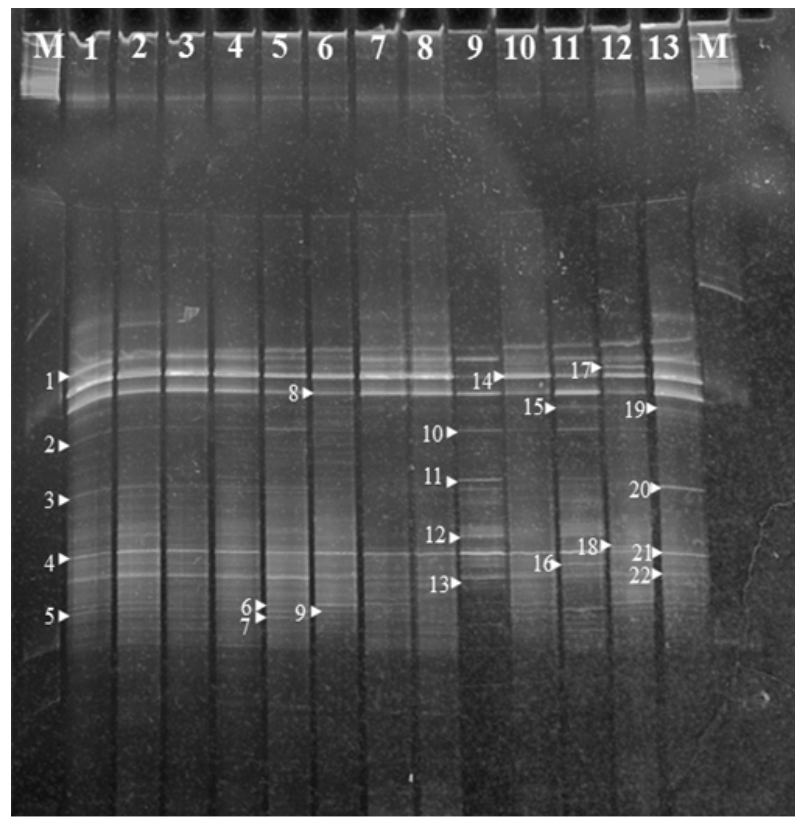

Fig. 5. PCR-DGGE based microbial community analysis of mudflat (demonstration site) after remediation using the CAJ System and water pumping system. Lanes: M, marker; 1, 2, 3, 4 and 5, a-1, a-2, a-3, a-4 and a-5; 6, 7, 8, 9 and 10, p-1, p-2, p-3, p-4 and p-5; 11, before treatment; 12,7 days after air jet treatment; 13, 7 days after water pumping treatment.

\section{Microbial community analysis of the treated sites (demonstration and other field sites)}

Microbial community analysis based on PCR-DGGE of the mudflats (demonstration sites) after remediation was shown in Fig. 5. The community identification analysis results were shown in Table 2. Although most of these microbial communities have not been identified as oil degraders, most of them have been confirmed to be of sea and sediment origin. Even though the air jet system was supposed to stimulate oil degraders, the identified communities appeared to include little oil degraders. This may indicate that there were oil degrader populations with relatively low density if any. The low density might be due to the low concentration of TPH as a carbon source and limiting nutrients (nitrogen and phosphorus, etc.) and other limiting factors (temperature, etc.). The microbial community profiles of all samples including control (before treatment) appeared to be quite similar except bands 15 and 16 which were uniquely present in the control. The gradual community change was observed over a week period as bands 17 and 18 were unique in the air jet treatment and the bands 19, 20, 21, and 22 in the pumping treatment. The fate of these communities will be contingent upon environmental conditions ahead in the sites (e.g., available sources of substrates such as $\mathrm{C}, \mathrm{N}$, and $\mathrm{P}$, and competing microbial communities and grazers). Epsilon proteobacterium (bands 1, 2, 3, and 14) was dominant species

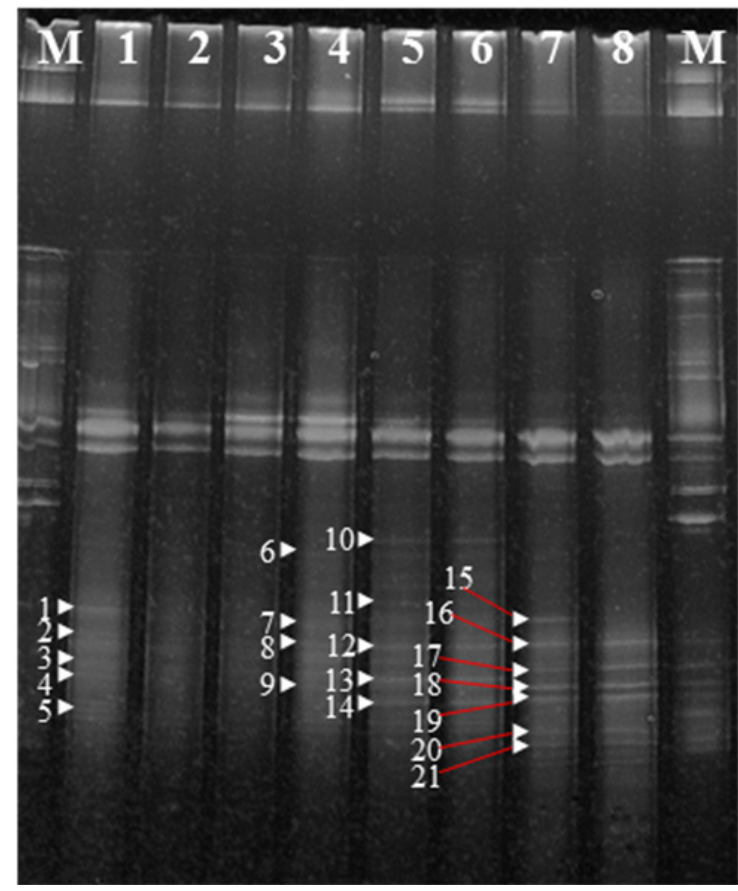

Fig. 6. PCR-DGGE based microbial community analysis of mudflat (field sites) after remediation using the CAJ System; Lanes: 1, 2, Cheonripo down; 3, 4, Cheonripo mix; 5, 6, Guryepo; and 7, 8, Haenyumaeul (pumping as control); all samples were run in duplicate. 
Table 2. Identification of microbial communities based on sequence analysis of 16S DNA amplified from DNA fragments derived from PCR-DGGE (Fig. 5)

\begin{tabular}{|c|c|c|c|c|}
\hline $\begin{array}{l}\text { Band } \\
\text { No. }\end{array}$ & $\begin{array}{l}\text { Accession } \\
\text { No. }\end{array}$ & Description & Source & $\begin{array}{l}\text { Identity } \\
(\%)\end{array}$ \\
\hline 1 & AY280396 & $\begin{array}{l}\text { Uncultured epsilon proteobacterium clone } \mathrm{CH}-\mathrm{B} 30 \\
16 \mathrm{~S} \text { ribosomal RNA }\end{array}$ & $\begin{array}{l}\text { Active Deep-Sea Vent Chimney Juan de Fuca Ridge, } \\
\text { Pacific Ocean }\end{array}$ & 95 \\
\hline 2 & DQ112521 & $\begin{array}{l}\text { Uncultured epsilon proteobacterium clone } \\
\text { KorMud-V8C120 16S }\end{array}$ & Intertidal mudflat sediment Ganghwa Island, Korea & 99 \\
\hline 3 & DQ112521 & $\begin{array}{l}\text { Uncultured epsilon proteobacterium clone } \\
\text { KorMud-V8C120 16S }\end{array}$ & Intertidal mudflat sediment Ganghwa Island, Korea & 99 \\
\hline 4 & AM911409 & $\begin{array}{l}\text { Uncultured bacterium partial 16S rRNA, clone } \\
\text { D05_CW03_full }\end{array}$ & $\begin{array}{l}\text { Cold-water coral, Lophelia pertusa, S. C Neulinger, } \\
\text { Norway }\end{array}$ & 99 \\
\hline 5 & HM368279 & $\begin{array}{l}\text { Alpha proteobacterium HA-mar-Is18-14 16S } \\
\text { ribosomal RNA gene }\end{array}$ & Estuarine and marine bacteria, Wadden Sea, German & 99 \\
\hline 6 & GQ143753 & $\begin{array}{l}\text { Uncultured bacterium clone } 069 \mathrm{C} 7916 \mathrm{~S} \text { ribosomal } \\
\text { RNA gene }\end{array}$ & Yellow Sea continental shelf sediment & 99 \\
\hline 7 & EU652622 & $\begin{array}{l}\text { Uncultured bacterium clone D8S-50 16S ribosomal } \\
\text { RNA gene }\end{array}$ & $\begin{array}{l}\text { Yellow Sea sediment, } \\
\text { Korea }\end{array}$ & 98 \\
\hline 8 & HM366476 & $\begin{array}{l}\text { Uncultured bacterium clone ADB-16 16S ribosomal } \\
\text { RNA gene }\end{array}$ & $\begin{array}{l}\text { Urban aerosols } \\
\text { Seoul, Korea }\end{array}$ & 99 \\
\hline 9 & AB530225 & Uncultured bacterium gene for $16 \mathrm{~S}$ rRNA & Marine sediment, Tokyo Bay & 99 \\
\hline 10 & NR_025817 & $\begin{array}{l}\text { Erythrobacter seohaensis strain SW-135 16S } \\
\text { ribosomal RNA }\end{array}$ & Yellow sea continental shelf sediment & 99 \\
\hline 11 & AY161043 & Brevibacillus sp. PLC-3 16S ribosomal RNA gene & Brevibacillus sp. PLC-3 & 97 \\
\hline 12 & DQ341414 & $\begin{array}{l}\text { Pseudomonas sp. Antarctic IS02 16S ribosomal RNA } \\
\text { gene }\end{array}$ & Antarctic ice and snow & 99 \\
\hline 14 & AY580419 & $\begin{array}{l}\text { Uncultured epsilon proteobacterium clone PI_4t12b } \\
16 \mathrm{~S} \text { ribosomal RNA gene gene }\end{array}$ & $\begin{array}{l}\text { Plum Island Sound Estuary, northeastern } \\
\text { Massachusetts }\end{array}$ & 100 \\
\hline 15 & AB441527 & $\begin{array}{l}\text { Uncultured bacterium gene for } 16 \mathrm{~S} \text { rRNA, partial } \\
\text { sequence, clone; CC } 35\end{array}$ & $\begin{array}{l}\text { Solid waste compost, } \\
\text { Japan }\end{array}$ & 99 \\
\hline 16 & AB530205 & $\begin{array}{l}\text { Uncultured bacterium gene for } 16 \mathrm{~S} \text { rRNA, partial } \\
\text { sequence }\end{array}$ & Marine sediment, Tokyo Bay & 98 \\
\hline 17 & DQ521175 & $\begin{array}{l}\text { Uncultured bacterium clone C53 16S ribosomal RNA } \\
\text { gene, partial sequence }\end{array}$ & $\begin{array}{l}\text { Sediment of cold hypersaline ( } 15 \% \text { salt) sulfidic } \\
\text { spring, Arctic }\end{array}$ & 98 \\
\hline 18 & AB441527 & $\begin{array}{l}\text { Uncultured bacterium gene for } 16 \mathrm{~S} \text { rRNA, partial } \\
\text { sequence, clone; CC } 35\end{array}$ & Solid waste compost, Japan & 100 \\
\hline 19 & AY580419 & $\begin{array}{l}\text { Uncultured epsilon proteobacterium clone PI_4t12b } \\
16 \mathrm{~S} \text { ribosomal RNA gene }\end{array}$ & $\begin{array}{l}\text { Coastal bacterioplankton sample of Plum Island } \\
\text { Sound Estuary, northeastern Massachusetts }\end{array}$ & 100 \\
\hline 20 & GU553835 & $\begin{array}{l}\text { Uncultured bacterium clone } \\
\text { ORI-860-27-P_W_27WB08 16S ribosomal RNA } \\
\text { gene, partial sequence }\end{array}$ & Methane seep of YungAn ridge, SW Taiwan & 100 \\
\hline 21 & U85879 & $\begin{array}{l}\text { Psychrobacter glacincola ICP9 16S ribosomal RNA } \\
\text { gene, partial sequence }\end{array}$ & Psychrophilic bacteria in Antarctic sea ice & 100 \\
\hline 22 & AM040115 & Uncultured delta proteobacterium & $\begin{array}{l}\text { Sandy intertidal sediments in the North Sea, } \\
\text { Sylt-Romo Basin, Wadden Sea }\end{array}$ & 100 \\
\hline
\end{tabular}

almost for all the samples that was widely observed in the ocean and terrestrial environments (Campbell et al., 2006).

In the other on-site tests, the levels of TPH after treating with the CAJ System were not generally much lower than the control (water pumping treatment) (Fig. 4). Microbial community changes were also monitored using PCR-DGGE depending on the different field site treatments. Dominant species in
Cheonripo down and Cheonripo mix after treating with the CAJ System were different from dominant species in the control (seawater pumping; Haenyeomaeul). Even in sites treated with the same CAJ System, different microbial communities were shown. Most of these microorganisms were identified as marine bacteria originated from the marine environment (seawater or marine sediment) while the densities of the oil 
Table 3. Identification of microbial communities based on sequence analysis of 16S DNA amplified from DNA fragments derived from PCR-DGGE (Fig. 6)

\begin{tabular}{|c|c|c|c|c|}
\hline $\begin{array}{l}\text { Band } \\
\text { No. }\end{array}$ & $\begin{array}{l}\text { Accession } \\
\text { No. }\end{array}$ & Description & Source & $\begin{array}{c}\text { Identity } \\
(\%)\end{array}$ \\
\hline 1 & AY711463 & $\begin{array}{l}\text { Uncultured Chromatiales bacterium clone SIMO-2097 } \\
\text { 16S ribosomal RNA }\end{array}$ & Dean creek marsh sediment, Sapelo Island, USA & 98 \\
\hline 2 & EU050805 & $\begin{array}{l}\text { Uncultured gamma proteobacterium clone } \\
\text { SS1_B_04_19 16S ribosomal }\end{array}$ & sediment from the Kings Bay, Svalbard & 98 \\
\hline 3 & AY568822 & $\begin{array}{l}\text { Uncultured bacterium isolate } \\
\text { JH10_C70 16S ribosomal RNA }\end{array}$ & Intertidal mudflate sediment, Ganhwa, Korea & 99 \\
\hline 4 & FJ227884 & $\begin{array}{l}\text { Uncultured bacterium clone } \\
\text { ESSM071205_802H3AOB 16S ribosomal RNA }\end{array}$ & $\begin{array}{l}\text { marine sediment California, Elkhorn Slough, South } \\
\text { Marsh. }\end{array}$ & 95 \\
\hline 5 & HM437482 & $\begin{array}{l}\text { Uncultured marine bacterium clone B-Alg14 16S } \\
\text { ribosomal RNA }\end{array}$ & Surface of senescence algea, Jiaozhou Bay, China & 99 \\
\hline 6 & DQ112521 & $\begin{array}{l}\text { Uncultured epsilon proteobacterium } \\
\text { clone KorMud-V8C120 16S }\end{array}$ & Intertidal mudflate sediment, Ganhwa, Korea & 99 \\
\hline 7 & FJ717246 & $\begin{array}{l}\text { Uncultured bacterium clone G6_10.4_2 16S } \\
\text { ribosomal RNA gene }\end{array}$ & Marine sediment from Cullercoats, UK & 98 \\
\hline 8 & AY771946 & $\begin{array}{l}\text { Uncultured delta proteobacterium clone SK11 16S } \\
\text { ribosomal RNA gene }\end{array}$ & Marine surface sediment; Waden, Germany & 99 \\
\hline 9 & EU287287 & $\begin{array}{l}\text { Uncultured bacterium clone } \\
\text { S11-104 16S ribosomal RNA gene }\end{array}$ & Artic surface sediment pacific ocean & 98 \\
\hline 10 & GQ143753 & $\begin{array}{l}\text { Uncultured candidate division TM6 bacterium clone } \\
\text { JJB103 16S }\end{array}$ & Yellow sea continental shelf sediment & 90 \\
\hline 11 & AB530235 & $\begin{array}{l}\text { Uncultured bacterium gene for } \\
16 \mathrm{~S} \text { rRNA, partial sequence }\end{array}$ & Marine sediment, Tokyo Bay, Japan & 97 \\
\hline 12 & AJ557849 & Marine arctic deep-sea bacterium HG1 & $\begin{array}{l}50 \mathrm{~m} \text { above sediment surface, arctic current from } \\
\text { North Pole }\end{array}$ & 99 \\
\hline 13 & DQ357036 & $\begin{array}{l}\text { Loktanella sp. K0-28-006 16S ribosomal RNA gene, } \\
\text { partial sequence }\end{array}$ & $\begin{array}{l}\text { Deep sea sediment core DMO5-2907, Okinawa, } \\
\text { Japan }\end{array}$ & 99 \\
\hline 14 & AY592607 & $\begin{array}{l}\text { Uncultured bacterium clone Napoli-1B-52 16S } \\
\text { ribosomal RNA gene }\end{array}$ & Napoli mud volcano; isolated from sediment layer & 99 \\
\hline 15 & HM030990 & $\begin{array}{l}\text { Marine bacterium KS-9-10-4 16S ribosomal RNA } \\
\text { gene, partial }\end{array}$ & $\begin{array}{l}\text { Marine bacterium Ruditpes philinarum isolated from } \\
\text { South Korea }\end{array}$ & 99 \\
\hline 16 & GQ245896 & $\begin{array}{l}\text { Marinobacterium rhizophilum strain UDC307 16S } \\
\text { ribosomal RNA gene }\end{array}$ & Sea water, Dokdo, South Korea & 99 \\
\hline 17 & AM998269 & $\begin{array}{l}\text { Uncultured deep-sea bacteriumpartial 16S rRNA gene, } \\
\text { clone }\end{array}$ & $\begin{array}{l}\text { Deep-sea surface sediments, Guinea Basin, Atlantic } \\
\text { Ocean }\end{array}$ & 99 \\
\hline 18 & FJ264673 & $\begin{array}{l}\text { Uncultured bacterium clone OrigSedB32 16S } \\
\text { ribosomal RNA gene }\end{array}$ & Methane seep sediment. Eel River Basin, CA,USA & 97 \\
\hline 19 & GU475276 & $\begin{array}{l}\text { Uncultured bacterium clone DSH1B } 2816 \text { S ribosomal } \\
\text { RNA gene }\end{array}$ & Cold seep sediment, south China sea & 97 \\
\hline 20 & FJ175562 & $\begin{array}{l}\text { Uncultured bacterium clone B5-8 16S ribosomal RNA } \\
\text { gene }\end{array}$ & Hydrocarbon seep sediment in Timor Sea, Asyralis & 99 \\
\hline 21 & GQ263399 & $\begin{array}{l}\text { Uncultured bacterium clone FW1_b8316S ribosomal } \\
\text { RNA gene }\end{array}$ & $\begin{array}{l}\text { Simulated low level waste site Idaho National Labs, } \\
\text { USA }\end{array}$ & 97 \\
\hline
\end{tabular}

degraders seemed to be relatively low. Therefore, distribution of the microbial communities under the current condition having relatively very low oil contamination (less than $160 \mathrm{ppm}$ of TPH) was attributed to differences in environmental characteristics rather than the oil treatment measures.

The conclusions were drawn as follows: The compressed air jet technology appeared to be highly effective to remove TPH from soil matrices contaminated with crude oil. The air jet system showed different microbial communities from the conventional water pumping treatment system. However, oil degraders were not observed mainly because of lower amount of oil as a carbon source and depleted nutrients (particularly $\mathrm{N}$ and $\mathrm{P}$ ) in the environment. Mechanisms associated with the removal of oil or contaminants using the air jet system need to 
be elucidated in the future study. It would be possible to apply the air jet system to removal of other pollutants as one of the economical and eco-friendly remediation technologies.

\section{적 요}

본 연구의 목표는 압축공기분사시스템을 이용하여 원유로 유 출이 된 해안을 정화함에 있어서 그 정화효율성과 정화 전후의 총석유탄화수소(total petroleum hydrocarbon; TPH) 농도 및 미 생물군집변화를 관찰함으로써 그 최적 정화과정을 이해하기 위 한 기초자료를 얻고자 하는 것이다. 압축공기제트시스템을 2-5 회 연속적용 시 오염지의 TPH가 약 $66 \%$ 까지 저감이 된 반면에 대조구인 해수를 펌핑한 경우에는 $40 \%$ 정도의 저감효과가 관찰 이 되었다. 압축공기의 분사 후 PCR-DGGE에 의한 미생물군집 분석 결과에서는 유류분해미생물의 군집은 확인이 되지 않았다. 이는 정화에 의한 낮은 $\mathrm{TPH}$ 농도(약 $100 \mathrm{mg} / \mathrm{kg}$ 수준, 탄소원), 처리환경에 내재적인 제한적인 질소 및 인의 농도에 기이한 것 으로 판단된다. 따라서 잔여분의 유류는 에어제트시스템을 적용 시 제한적 영양염류(질소 및 인 등)를 적절한 방식과 농도로 투 여할 경우 거의 완전하게 제거가 가능할 것으로 사료된다. 향후 본 기술은 고농도의 유류 및 유기물로 오염된 다양한 수질환경 및 토양환경의 효율적이고 환경친화적인 정화에 활용이 될 것으 로 기대된다.

\section{Acknowledgements}

This work is an outcome of the Manpower Development Program for Marine Energy by the Ministry of Oceans and Fisheries, and Korea Maritime and Ocean University's Research Initiation Support Program for New Faculty Members.

\section{References}

Altas, R.M. 1981. Microbial degradation of petroleum hydrocarbons: an environmental perspective. Microbiol. Rev. 45, 180-209.
Altas, R.M. and Bartha, R. 1992. Hydrocarbon biodegradation and oil spill bioremediation. Adv. Microb. Ecol. 12, 287-338.

Bejarano, A.C. and Michel, J. 2010. Large-scale risk assessment of polycyclic aromatic hydrocarbons in shoreline sediments from Saudi Arabia: Environmental legacy after twelve years of the Gulf war oil spill. Environ. Pollut. 158, 1561-1569.

Campbell, B.J., Engel, A.S., Porter, M.L., and Takai, K. 2006. The versatile $\varepsilon$-proteobacteria: key players in sulphidic habitats. Nat. Rev. Microbiol. 4, 458-468.

Choi, K.S., Kim, S.H., Jeong, Y.K., Jang, K.L., and Lee, T.H. 1997. Production of biosurfactant by Tsukamurella sp. 26A. Kor. J. Microbiol. 33, 187-192.

De Acevedo, G.T. and McInnemey, M.J. 1996. Emulsifying activity in themophilic and extremely thermophlic microorganisms. J. Inst. Microbiol. 16, 1-7.

Ekpeghere, K.I., Bae, H.J., Kwon, S.H., Kim, B.H., Park, D.Ja, and Koh, S.C. 2009. Clean-up of the crude oil contaminated marine sediments through biocarrier-mediated bioaugmentation. Kor. J. Microbiol. 45, 354-361.

Femández-Luqueño, F., Valenzuela-Encinas, C., Marsch, R., MartínezSuárez, C., Vázquez-Núñez, E., and Dendooven, L. 2011. Microbial communities to mitigate contamination of PAHs in soild possibilities and challenges: a review. Environ. Sci. Pollut. Res. 18, 12-30.

Koh, S.H., Lee, H.K., and Lee, S.J. 1998. Effect of hydrocarbon uptake modes on oil degradation rate by mixed cultures of petroleum degraders. KSBB J. 13, 606-614.

Ministry of Environment, Government of Republic of Korea. 2009. Official standard methods for contaminated soils.

Roenberg, E. and Ron, E.Z. 1997. Bioemulsans: microbial polymeric emulsifiers. Curr. Opin. Biotechnol. 8, 313-316.

Seo, E.Y. and Song, H.K. 1994. Effects of diesel oil on the population and activity of soil microbial community. Kor. J. Microbiol. 32, 163171

Sprocati, A.R., Alisi, C., Tasso, F., Marconi, P., Sciullo, A., Pinto, V., Chiavarini, S., Ubaldi, C., and Cremisini, C. 2012. Effectiveness of a microbial formula, as a bioaugmentation agent, tailored for bioremediation of diesel oil and heavy metal co-contaminated soil. Proc. Biochem. 47, 1649-1655.

Zhang, Y. and Miller, R.M. 1994. Effect of a Pseudomonas rhamnolipid biosurfactant on cell hydrophobicity and biodegradation of octadecane. Appl. Environ. Microbiol. 60, 2101-2106. 